\title{
Kişilik Özellikleri ve Zaman Hırsızlığı İlişkisi: TRA1 ve TRB2 Bölgeleri Otel İşgörenleri Üzerinde Bir Araştırma ${ }^{1}$
}

\author{
The Relationship Between Personality Traits and Time Theft: A Study on Hotel Employees in TRA1 and \\ TRB2 Regions
}

\author{
Ayça Sena ÖNALAN ${ }^{a}$, Songül ÖZER ${ }^{b}(\mathbb{0}$ \\ a Van Yüzüncü Yıl Üniversitesi, Sosyal Bilimler Enstitüsü, Turizm İşletmeciliği A.B.D., Van, Türkiye. \\ b Dr. Öğr. Üyesi, Van Yüzüncü Yıl Üniversitesi, Turizm Fakültesi, Rekreasyon Yönetimi Bölümü, Van, Türkiye.
}

\begin{abstract}
Özet
Bu araştırmanın amacı, kişilik özellikleri ile zaman hırsızlığı arasındaki ilișkiyi ve etki düzeyinin tespit etmektir. Bu kapsamda araştırmanın evrenini TRA1 ve TRB2 bölgelerinde bulunan 4 ve 5 yıldızlı otel işgörenleri oluşturmaktadır. Bu doğrultuda evreni oluşturan oltel işgörenlerine anket uygulanmıştır. Çalışma kapsamında öncelikle kişilik özellikleri ve zaman hırsızlığı kavramlarına ilişkin gerekli alan yazın taraması yapılmıştır. Akabinde TRA1 ve TRB2 bölgelerinde faaliyet gösteren dört ve beş yıldızlı otel işgörenlerinin, katılımlarının sağlandığı kişilik özellikleri ve zaman hırsızlığı davranış eğilimlerini ölçmeye yönelik ifadeleri içeren anket uygulanmıştır. Söz konusu anket uygulaması ile aynı zamanda; araştırmanın amaçları dâhilinde katılımcıların kişilik özellikleri ile zaman hırsızlığı eğilimleri arasında nasıl bir ilişki olduğu saptanmıştır. Devamında katılımcıların kişilik özelliklerinin zaman hırsızlığı eğilimleri üzerindeki etkisi de ölçülmüştür. Veri toplama aracı olarak kullanılan anket formu, geçerlilik ve güvenilirliği test edilmiş ölçeklerden oluşturulmuş olup, toplam 386 işgörene uygulanmıştır.

Araştırma sonucunda otel işgörenlerinin genel olarak kişilik özellikleri ve zaman hırsızlığ eğilimleri arasında anlamlı bir ilişki olmadığı tespit edilmiştir. Ancak işgörenlerin kişilik özelliklerinin zaman hırsızlığı davranışları üzerinde düşük düzeyde anlamlı bir etkisi olduğu tespit edilmiştir. Diğer bir ifade ile otel işgörenlerinin sahip olduğu kişilik özelliklerinin zaman hırsızlığ eğilimleri üzerinde etkili olduğu sonucu elde edilmiştir.
\end{abstract}

Anahtar Kelimeler: Kişilik, kişilik özellikleri, zaman hırsızlığı, otel işgörenleri, TRA1, TRB2.

\begin{abstract}
The goal of this study is to determine the relationship and the level of effect between personality traits and time theft. In this context, the population of the research consists of 4 and 5 star hotel employees in TRA1 and TRB2 regions. In this direction, a questionnaire was applied to the oltel employees who formed the universe. Within the scope of the study, first of all, the necessary literature review was conducted on the concepts of personality traits and time theft. Afterwards, a questionnaire was applied to measure the personality traits and time theft behavior tendencies of four and five star hotel employees operating in TRA1 and TRB2 regions. At the same time with the said survey application; Within the scope of the research, it was determined what kind of a relationship there is between the personality traits of the participants and their time theft tendencies. Afterwards, the effect of the participants' personality traits on their time theft tendencies were also measured. The questionnaire form, which was used as a data collection tool, was created from scales whose validity and reliability were tested and applied to a total of 386 employees.

As a result of the research, it has been determined that there is no significant relationship between the personality traits of hotel employees and their tendency to time theft. However, it has been determined that the personality traits of the employees have a low-level significant effect on their time theft behavior. In other words, it was concluded that the personality traits of the hotel employees were effective on the time theft tendencies.
\end{abstract}

Keywords: Personality, personality traits, time theft, hotel employees, TRA1, TRB2.
Makale Bilgisi

Geliş Tarihi

Kabul Tarihi

11.06.2021

24.06.2021

Sayı Editörü

Hacer Arslan KALAY

Sorumlu Yazar

Ayça Sena Önalan

aycasena_@hotmail.com (2)

\section{Önerilen Atıf:}

Önalan, A. S. ve Özer, S., (2021). Kişilik Özellikleri ve Zaman Hırsızlığı İlişkisi: TRA1 ve TRB2 Bölgeleri Otel İşgörenleri Üzerinde Bir Araştırma, Journal of Academic Tourism Studies, 2(1): 61-77. 


\section{GİRIŞ}

Geçmişten günümüze kadar hemen her dönemde örgütler, faaliyetlerini sürdürebilmek için doğal, ekonomik, sosyal ve kültürel, çevresel birçok faktörden daimî olarak etkilendikleri söylenebilir. Devam eden ve değişen dünya yaşantısına paralel olarak bu faktörler de sürekli değişiklik göstermektedir. Son zamanlarda ise hızlı bir değişime uğrayan; bilgi akışı, iletişim ve teknoloji alanlarındaki ilerlemeler örgütler ve kişiler arası rekabeti artırma eğilimi gösterebilir. Dolayısıyla örgüt ve kişilerin artan rekabete bağlı olarak artan sorumlulukları, yönetimsel iş yükünü de artırabilmektedir. Gittikçe yoğunlaşan iş yükü ve faaliyetlerin gerçekleştirilebilmesi için belirlenen zaman dilimleri elbette kişilerde baskıya neden olabilmektedir. Zira artış gösteren yoğunluklara karşın kullanılan zaman birimleri aynı kalmaktadır.

Günümüzde yöneticilerin başarısını veya başarısızlığını ortaya koyan belirgin ölçüt; zamanı akıllı, etkili ve verimli kullanma becerisi gösterilebilir (Aytürk, 2007:191). Zamanın boşa harcanması ve yanlış kullanılması noktasında "zaman hırsızlığı" ifadesi de bu değerli kaynağın israfı ve öldürülmesi halinin ne denli yanlış olduğunu açıklamak için ortaya çıkmış bir kavramdır. Genel olarak zamanın her türlü ziyan edilmesi durumunu ifade eden zaman hırsızlığı olgusu, örgütsel yaşamda işgörenlerin mesai saatlerinde sorumluluklarını ihmal ederek iş dişı faaliyetlerde bulunmaları olarak açıklanmaktadır. Zaman hırsızlı̆̆ı, işe mazeretsiz geç başlama, sanal kaytarma, iş saatlerinde sosyal aylaklık gibi davranışları da kapsamaktadır.

Zamanı yönetebilmek ve etkin kullanabilmek noktasında bireyler arasında farklılık söz konusu olabilmektedir. Bireyler doğuştan gelen veya daha sonra belirli etkenler doğrultusunda kendilerine has karakteristik özelliklere sahiptirler. Karakteristik özellikler insanların karşılaştıkları olaylara sergiledikleri davranış ve tepkileri belirlemektedir. Yaşanılan aynı olay karşısında bazı bireyler motivasyonel yaklaşırken bazı bireyler ise aksi şekilde reaksiyon gösterebilmektedir. Bu durum bireylerin farklı kişilik özelliklerine sahip olmalarından kaynaklanmaktadır. Bazen yaşanan deneyimlerden kaynaklanan farklı etkileşim tarzı yaşanırken bazen de bulunulan çevreden, ait olunan sosyal sinıftan veya üyesi olunan toplumdan etkilenmek olasıdır. Bu kişisel özellikler literatürde belli başlıklar halinde tasniflenmiştir.

Mizaç olarak zaman kavramını önemsemeyen ve işlerinde dakiklik göstermeyen bir birey bu davranışını örgüt hayatına yansıttı̆̆ı zaman zincirleme bir performans ve verim düşüklüğü yaşanabilmektedir. Bu durum örgüt açısından gerek ekonomik gerek sosyal ve prestij anlamında zararlar doğuracaktır. Özel hayat ve örgütsel hayatta bu ve benzeri zararların önüne geçebilmek için, öncelikli olarak zamanın etkin kullanılmasının önündeki engeller doğru bir şekilde belirlenmelidir. Bireyin kişilik özelliklerinin de bu engeller arasında olabileceği öngörüsü ve işgörenlerin kişilik özellikleri ile zamanı etkin kullanmaları arasında nasıl bir ilişki olduğunu saptamak bu çalışmanın yürütülme sebeplerindendir.

Çalışmanın temel amacı, kişilik özellikleri ile zaman hırsızlığı eğilimleri arasındaki ilişkiyi tespit edip, kişilik özelliklerinin zaman hırsızlığı eğilimleri üzerindeki etkisini ölçmektir. Çalışma kapsaminda belirlenen örneklem grubunu ise TRA1 ve TRB2 bölgelerinde bulunan 4 ve 5 yıldızlı otel işgörenleri oluşturmaktadır. Bu doğrultada yapılan araştırma sonucunda otel işgörenlerinin kişilik özellikleri ile zaman hırsızlığı davranışı arasında anlamlı bir ilişki saptanmadığı, ancak işgörenlerin kişilik özelliklerinin zaman hırsızlığı davranışı üzerinde düşük düzeyde anlamlı bir etkisi olduğu sonucu ele edilmiştir.

\section{KAVRAMSAL ÇERÇEVE}

Kişilik olgusu uzun yıllardır araştırılmakta olup ve temelde; insanların neden farklılık gösterdikleri ya da aynı olaylar karşısında neden farklı tepkiler verdikleri sorularına cevap aranması ile daha da üzerinde durulan bir konu haline gelmiştir. Kişilik olgusuyla ilgili yapılanlar ise bu kavrama ilişkin bilim insanları ve düşünürlerin birbirlerine benzer ya da farklı bakış açılarına sahip oldukları görülmektedir (Sevi, 2009: 1). Zamanla bu kelime her bireyin hayattaki rolünü anlatmak 
için, kişi sözcüğünü ifade etmek amacıyla kullanılmıştır. Kişi ifadesini kullanırken ise akla ilk gelen şey insan olgusudur. İnsanların doğduğu günden itibaren belirli etmenler doğrultusunda edindikleri roller ile kendilerini temsil eden birtakım özellikler barındırmaktadırlar. Kişiler için kendilerine has olarak nitelendirilen bu özellikler kişilik olarak ifade edilmektedir (Ergün, 2017:34). Geçmişten bugüne kadar ilgi görmüş olan kişilik olgusu bilimsel olarak 1930 ve onu seyreden yıllarda üzerinde durulmaya başlanmıştır (Özyılmaz ve Gülbetekin, 2018: 234).

Kişiliğin oluşum ve gelişim süreçleri ile ilgili birçok teori ortaya atılmış olup, genel hatlarıyla her biri insan davranışlarını anlamlandırmak, açıklamak ve kontrol etmek için geliştirilmiş kavramsal sistem olma niteliği taşımaktadırlar. Bu teoriler farklı bakış açıları ile geliştirilmiş olsalar da birbirleri ile ilişkilidirler. Kişilik kuramları, karmaşık bir kavram olan kişiliğin daha anlaşılabilir hale getirilebilmesi amacı ile oluşturulmuştur. Kişilik teorilerinin her biri, kişilerin gelişimlerinin sürdürdüğü her bir alana ayrı ayrı odaklanmaktadır ve diğer alanlarla da bütünlük sağlayacak şekilde oluşturulmaktadır. Tarihin her döneminde çoğu düşünür tarafından kişilik olgusu ile ilgili kuramlar oluşturulmuştur. Ancak, 18. Yy'dan sonra bilimsel olarak kişilik teorileri anlam kazanmıştır. Başlangıç aşamalarında gözlemler sonucu görüşler öne sürülmüştür. Bunlar, Charcot, Janet, Freud, Jung ve McDougall gibi araştırmacılar tarafından derinlemesine incelenmiştir (Sevi, 2009: 2). Kişilik teorilerinin her biri, oluşturan kuramcı tarafından, kendi kişisel yaşamı ve olaylara bakış açısından etkilenerek hayata geçirilmiştir. Bu durum gözlenen olayın gözlemci tarafından yorumlanmasından mütevellit farklı kişilik teorilerinin meydana gelmesi sonucunu doğurmuştur (Yazgan-İnanç ve Yerlikaya, 2008: 6). Kişilik oluşumunun incelenmesini temel alan bu teorilerden en önemlileri, Sigmund Freud'un, Erik Erikson'un, Alfred Adler'in ve Carl Gustav Jung'un geliştirmiş olduğu kişilik kuramlarıdır.

Kişilik özellikleri bireyi diğerlerinden farklı kılar. Başka bir ifade ile kişilik özellikleri ayırt edicidir. Kişiliğin ayırt edici olması bireyi özgün kılan eğilim ve davranış setlerini ifade etmektedir. Bireyler zaman zaman benzer davranışlar sergilemelerine rağmen kendilerini özgün kılan birtakım özelliklere sahiptirler ve bu durum bireyi diğer bireylerden farklılaştırır. Bu farklılığın temelinde ise bireylerin sergiledikleri davranış eğilimlerinin yoğunluğu ve sıklığı yer almaktadır. Fiziksel, zihinsel ve duygusal yönden pek çok farklılık gösteren bireyler, bunun sonucunda olayları ve olguları da farklı şekilde yorumlarlar. Bu farklılıklar kişiliğin temelini oluşturur (Buchanan ve Huczynski, 1997: 136, 137). Ayrıca sergilenen belirli bir davranış yanlızca tek bir kişilik özelliğine değil birçok kişilik özelliğine dayandırılabilmektedir (Sevi, 2009: 4). Kişilik özelliklerinin genel olarak tutarlılık gösterdiği kanısı yaygın olup, bu kanı kişilik özelliklerinin değişmeyeceği anlamını ifade etmemektedir. Bilakis bireyin geçmiş yaşamı, deneyimleri ve edindiği yaşam tarzı onun kişilik özelliklerinin değişmesini etkileyen faktörlerdendir. Ancak geçici ya da kısa vadeli dönemsel şartlar bireylerin tesadüfi tepkiler vermesine sebep olabilir. Bu durum kişilik özelliklerinin değiştiği anlamına gelmemektedir. Tanımlama yapılırken bu özelliklerin, tutarlılık kelimesi ile ifade edilmesi de davranışların sık sık değişmeyeceğinden mütevellittir. Bireyin işlerini zamanında yapması ve dakik olması o kişinin genel olarak dakik olduğunun işaretidir ve bu durum karakteristik bir özelliktir. Aksi bir olayın yaşanması durumunda bahsedilen bu kişinin geç kalması onun bu özelliğini kaybetmesine neden olmaz. Kişilik özelliklerinin insanların geçmişinde şekillenmeye başlayıp yaşamin ilerleyen dönemlerinde de devam ettiği savını destekleyen örnekler de çoğaltılabilir. (Buchanan ve Huczynski, 1997: 136-137)

Alan yazında kişilik ile alakalı yapılmış çoğu çalışmaya konu olan, insanların kişilik özellikleri ile dışa vurduğu tepkileri, davranışları arasındaki ilişkiyi temel alarak kişilikleri inceleyen "beş faktör kişilik kuramı" kişilik özellikleri ile ilgili esas alınabilecek önem arz eden bir modeldir. Bu model, neredeyse 50 yıl boyunca devam etmiş çalışmaların neticesi olarak ortaya atılan ve McCrae ve Costa tarafından açıklanan bir kuramdır (McCrae ve Costa, 1995:81). Bireylerin kendilerine has tutum ve davranışlarının daha iyi tanımlanabilmesi açısından geliştirilen beş faktör kişilik modeli kişilere özgü belirli sıfatların sınıflandırılmasından oluşmaktadır. Kişisel özelliklerini ifade eden çok sayıda sıfat olabileceğinden (örn; sempatik, utangaç, sessiz, yenilikçi, konuşkan vb.) birbiri ile ilişkili olabilecek benzer sıfatlar aynı başlık altında toplanarak açıklanmaktadır. Bahsi geçen beş 
faktörü kişilik modeli ise: “duygusal olarak tutarsızlık, yenilikçilik, uyumlu olmak, sorumluluk bilinci, dışadönük" ifadelerinden oluşmaktadır (Çoklar, 2014: 32). Özellikle son yıllarda kişilik özelliklerini temel alan araştırmalarda ise bu beş faktörün etkisinin olduğunu belirtmek de mümkündür (Somer, 1998:27). Toplamda 5 başlık altında toplanan bu modelin içerikleri aşağıda ayrı ayrı olarak sunulmuştur.

- Dışadönüklük: Dışadönük insanlar, diğer insanlarla bir arada olmayı seven, topluma uyum sağlayan ve sosyal bir kişi olma özelliğine sahip olup, hareketli ve canlı bireyleri de kapsamaktadırlar. Dışadönük kişilik boyutuna dahil olan bireyler aynı zamanda, karşılaştıkları durumları abartmayı severler. Hırslı ve baskın karakterleri ile de dikkat çekerler (Trouba, 2007: 9).

- Uyumluluk: Ilımlı ve uzlaşan insan tiplerini kapsayan bu faktör, aynı zamanda diğer insanlarda güven duygusu uyandıran kişilerin de dahil olduğu faktördür. Açık sözlülük, alçakgönüllülük de bu faktörün kapsadığı kişilik özellikleri arasında yer almaktadır. Bireyle arasında uyumluluk özelliğini taşıyanlar, genelde etrafındaki insanların kendilerinden hoşlanmalarına önem vermekte olup, çatışmadan kaçınmayı tercih ederler. Düşük seviyede uyumluluk özelliğini taşıyan insanlar, görüşlere fazla önem vermeyip, şüpheci oluşlarıyla da dikkat çekerler (Turban ve Lee, 2007: 38).

- Nevrotiklik: Bu faktör Costa ve McCrae (1992) tarafından açılanmıştır. Daha çok heyecanlı, telaşlı, tedirgin, güvensiz ve sinir seviyesi yüksek olan kişileri niteleyen faktördür. Kişilerin duygusal bakımdan dengeli olmaları halinde sakin, dirayetli, rahat ve özgüvenli tipler ortaya çıkarken, bilakis duygusal olarak dengesizlik gösteren bireyler (Nevrotiklik), daha gergin, olumsuz düşüncelere sahip ve kendilerini güvende hissetmeyen tipler olarak görülmektedirler (Hashim vd., 2013: 771).

- Yenilik ve Girişime Açıklık: Yenilikçi kişilik modeli, genel hatlarıyla kişiler arası ilişkileri çok iyi olmayan, yeni fikirlere ve yeniliklere açık olan kişileri kapsamaktadır. Aynı zamanda kabul görme arzusu yüksek olan olan, girişken, meraklı, hayal gücü geniş olan bireyleri de içine alan gruptur. Açıklık ve yenilik boyutu kapsamında olan bireyler, yaratıcılığa ilişkin bir yönleri ve diğerlerine nazaran daha aykırı düşünmeye eğilimli olduklarından zihinsel açıdan zekâ ile paralel yönlü bir ilişkidedir. Bu boyuta dahil olan bireylerin karakteristik özelliklerini açıklarken yenilikçi oluşlarına odaklanmak gerekir. Bu tip kişiler yaratıcı olma ve yeni çıktılar üretmek konusunda oldukça isteklidirler (Çetin ve Varoğlu 2009: 60).

- Sorumluluk: Denetim ve disiplin üzerine kurulu bu boyut, düzenli ve hedefleri doğrultusunda planlı ilerleyen kişileri kapsamaktadır. Bu kişilik tipine sahip insanlar, diğer insanlara kıyasla daha dürüst, güvenilir ve dikkatli oluşlarılla ön plana çıkarlar. Bu kişilik özelliğine sahip olmayan insanlar da ise tam aksi durumlar mevcuttur. Disiplini, kural ve normları önemseyen insanların dahil olduğu bu kişilik modeline düşük seviyede sahip olan bireyler ise dürtü kontrolünde sıkıntı yaşamaktadırlar (Soto vd., 2015).

Zaman kavramı çok geniş perspektiflerde ele alınmaktadır. Zaman kavramına ilişkin birçok tanımlama yapılmıştır. Sucu'ya (1996: 3) göre zaman; soyut bir olgu olup, kişilerin zihinlerinde oluşturduğu ve olayların da bu oluşumun içinde akıp gittiği başlangıcı ve bitişi net olarak bilinmeyen bir kavramdır.

Zaman hırsızlığ ise, genel olarak işgörenlerin mesai saatleri içerisinde iş dışı faaliyetlerde bulunmalarını ifade etmektedir. Günlük yaşamda kişilerin bireysel işleri içinde zamanı doğru yönetememe halleri de olumsuz sonuçlar doğurmaktadır. İşgörenlerin zaman hırsızlığ1 davranışlarına örnek olarak; işe zamanında gitmemek, mesai bitmeden ayrılmak, mesai saatleri içerisinde telefon görüşmeleri, sosyal medyada gezinmek vb. davranışlarda bulunmak, görev ve sorumluluklara yeterince odaklanmamak gösterilebilir (Chen ve Tang, 2006). 
Zamanın verimli ve etkin kullanılmasına engel olan davranışlar kişilerden kaynaklı veya ortamdan kaynaklı birçok değişkene bağlı olabilmektedir (Rodoplu, 2001: 42). Zamanın verimli kullanılması noktasında karşılaşılan engeller, konu ile ilgili literatürde rastlanan bazı çalışmalarda zaman tuzakları şeklinde ele alınmaktadır. Bahsi geçen bu tuzakları Akyüz, Yılmaz ve Aldemir (2020: 416) üç şekilde ele almaktadır.

- Kişinin kendisinden kaynaklı engeller: kişisel hedeflerin olmaması, bireylerin kendisini yönlendirme ve yönetme noktasında zayıflı̆̆ ve temelde olan bireyin kişilik özelliklerinden kaynaklanan durumların varlığıdır.

- İş yeri ile alakalı karşılaşılan engeller: yapılan telefon konuşmalarının uzun süreli olması, iş ortamının elverişsiz olması gibi örnekler bu durum için gösterilmektedir.

- Organizasyon ve yönetimden kaynaklı engeller: iyi organize olamama ve bu doğrultuda bireyleri doğru yönlendirememe, hedef ve amaçlarda belirsizliklerin olması ve yetkiyi devretmeme gibi nedenler de zamanın kötüye harcanmasının nedenleri arasındadır.

Zaman hırsızlığı, özellikle örgütler açısından yüksek maliyetlere ve verimlilik kaybınına neden olmaktadır. Bugüne kadar zaman hırsızlığına dair araştırmalar yapılmış olsa da genel olarak ihmal edilmiş bir konudur. Zaman hırsızlığı, özellikle sanal kaytarma, sorumlulukların ertelenmesi, sosyal olarak yapılan aylaklıklar gibi birçok davranış için bir şemsiye olma niteliği taşımaktadır (Brock Baskin vd., 2017). Zamanı boşa geçirme ve verimliliğin kaybedilmesine yönelik sergilen çok sayıda davranış olması bu davranışların kategorilere ayrılması zorunluluğunu da beraberinde getirmektedir. Zira insanlar zamanı boşa harcarken işledikleri eylemler de farklılıklar gösterebilmektedirler. Kimileri işlerini erteledikleri vakitte teknolojiyle ilgilenirken, kimileri sorumluluklarını yerine getirmesi gereken zaman diliminde diğer insanlarla sosyalleşmeyi tercih etmektedirler. Kişilerin zamanı boşa geçirirken sergiledikleri bu uğraşlar genellikle üç boyut altında ele alınmaktadır. Bu boyutlar; 1- geleneksel zaman hırsızlığı, 2- teknolojik zaman hırsızlığı ve 3sosyal zaman hirsızlığıdır (Brock vd., 2013).

Zaman hırsızlığı davranışlarını boyutlarını ele alacak olursak; örneğin mesai saatleri içerisinde işgörenlerin internette kişisel ihtiyaçları için vakit geçirmeleri (Ding vd., 2018) teknolojik zaman hırsızlığı boyutu içerisinde yer almaktadır. Teknolojinin günümüzde hızlı ve yaygın bir kullanım alanına sahip olması çalışma hayatına da yansımaktadır. İşgörenlerin gerek iş ortamında gerekse özel yaşamlarında teknolojiyle iç içedirler. Örgütsel anlamda hızlı bir veri akışı sağlayabilmek adına ve bilgi dolaşımının da bir hayli hızlı olduğundan teknoloji kullanımı zaruri bir ihtiyaç haline gelmiştir. Bu zorunluluğun dışında işgörenler teknolojiyi kişisel amaçları için de kullanmaktadırlar. Özellikle iş yerinde ve mesai saatlerinde kendi özel gereksinimleri için teknolojiye zaman harcanması teknolojik bir zaman hırsızlığıdır. Ancak işgörenler sergiledikleri bu davranışların zaman kaybına yol açtı̆̆ını düşünmemektedir. Örneğin, iş yerinde bilgi dolaşımı kapsamında mail bekleyen bir işgörenin o esnada kişisel mail ve mesajlarını kontrol etmesi, o işgören için zamanı çalmak olarak ifade edilmemektedir. İşgören bunu zaman hırsızlığı olarak algılamasa da iş yerinde kişisel mesaj ve maillerin kontrol edilmesi teknolojik zaman hırsızlığı kapsamında yer almaktadır.

Zaman hırsızlığının bir başka boyutu olan sosyal zaman hırsızlığı da yine anlam olarak, işgörenlerin iş yerinde zamanı boşa harcayarak üretkenlik karşıtı davranışlarını ifade etmektedir. (Liu ve Berry, 2013). Bu davranışlara örnek olarak verilen iş arkadaşları ile mesai saatleri içerisinde uzun sohbetler etmek sosyal zaman hırsızlığı boyutu altında incelenebilir. Bunun yanı sıra işgörenlerin uzun molalara çıkması ve öğle yemeklerine geniş vakitler ayırmaları da sosyal zaman hırsızlığı olarak nitelendirilebilir.

Son olarak işe geç gelme, işten erken ayrılma ve gereksiz aralar vererek, zamanı boşa geçirmek gibi eylemler de geleneksel zaman hırsızlığı boyutu altında ele alınmaktadır. Geleneksel zaman hırsızlığı kapsamında, iş yerinde hayaller kurma, bilinçli olarak sorumlulukları yerine getirmeme, süreyi rahat kullanma ve çeşitli bahaneler ile işe devamsızlık yapma gibi davranışlar da örnek olarak gösterilebilir. 
Zaman hırsızlığı eğilimlerinin boyutlar altında incelenmesi zaman hırsızlığının farklı yönlerden araştırılmasına, öncüllerinin rahatlıkla belirlenmesine ve bu konu ile ilgili ölçeklerin geliştirilme süreçlerine de fayda sağlamaktadır.

Konu ile ilgili yapılmış çalışmaların incelenmesi sonucunda Babadağ ve Kerse (2019) tarafından zaman hırsızlığı ve kişilik özellikleri arasındaki ilişkiyi saptamaya yönelik yürüttükleri çalışmaya rastlanmıştır. Araştırmada kişilik özelliklerinin sorumluluk boyutunun zaman hırsızlığ1 üzerinde anlamlı etkisi olduğu sonucuna ulaşılmıştır. Uluslararası literatürde ise Brock, Martin ve Buckley (2013) tarafından yürütülen çalışmada zaman hırsızlığına ilişkin ölçek geliştirilmiş olup bunun yanı sıra zaman hırsızlığı ile kişilik özellikleri arasındaki ilişki ile ilgili önerilerde bulunulmuştur. Çalışma sonucunda elde edilen veriler doğrultusunda ise zaman hırsızlığının kişilik boyutları ile ilişkili olabileceği ileri sürülmüştür. Yine benzer şekilde uluslararası literatürde Brock Baskin vd. (2017) tarafından yürütülen çalışmada da kişilik özelliklerinin boyutlarının zaman hırsızlığı eğilimleri arasındaki ilişkiyi ele almıştır. Araştırma sonuçlarında kişiliğin boyutlarından olan nevrotiklik ile zaman hırsızlığı arasında anlamlı bir ilişki olduğu sonucu elde edilmiştir. Ayrıca bu ilişkinin pozitif yönlü olduğu da yine çalışma da saptanan sonuçlardandır. Yine aynı çalışma kapsamında ele alınmış olan kişiliğin dışadönüklük ve açıklık boyutları ile zaman hırsızlığı eğilimleri arasında anlamlı bir ilişki tespit edilmemiştir.

Ulusal ve uluslararası literatürde karşılaşılan, bu çalışma ile benzerlik gösteren yukarıdaki çalışmalar ve emsallerinin sonuçları ve tespitleri göz önünde bulundurularak hipotezler geliştirilmiştir.

Araştırma tasarımı doğrultusunda ve önceden yapılmış çalışmalara istinaden geliştirilen hipotezlere aşağıda yer verilmiştir:

Hipotez 1 (H1): işgörenlerin kişilik özellikleri ile zaman hırsızlı̆̆ı arasında anlamlı bir ilişki vardir.

Hipotez 2 (H2): İşgörenlerin kişilik özelliklerinin zaman hırsızlığı eğilimleri üzerinde anlamlı bir etkisi vardır.

\section{YÖNTEM}

Araştırmanın temel amacı, kişilik özellikleri ile zaman hırsızlığı eğilimleri arasındaki ilişkiyi ölçmektir. Aynı zamanda kişilik özelliklerinin zaman hırsızlığı eğilimleri üzerindeki etkisini ve bu etkinin düzeylerini saptamak da çalışmanın amaçlarındandır. Bu araştırmanın evrenini TRA1 (Erzurum, Erzincan, Bayburt) ve TRB2 (Van, Muş, Hakkâri, Bitlis) bölgelerinde faaliyet gösteren turizm işletme ve yatırım belgeli dört ve beş yıldızlı otel işgörenleri oluşturmaktadır. Çalışmanın evreni doğrultusunda bu bölgelerin içerisinde yer alan illerdeki il kültür turizm müdürlükleri ile iletişime geçilerek faaliyet gösteren dört ve beş yıldızlı otel sayılarına ulaşılmıştır. Evreni oluşturan otel işgören sayısına ulaşmak için ise ilgili otel işletmelerindeki yetkili kişiler ile görüşülmüştür. Otel işletmelerinden alınan cevaplar doğrultusunda ve çalışma yürütülürken karşılaşılan pandemi (salgın hastalık) sürecinden dolayı işgören sayılarında ciddi bir azalma olduğu sonucuna ulaşılmıştır. Bu nedenle örneklem alma yoluna gidilmiştir. Çalışmada kolayda örnekleme yöntemi seçilmiş olup, bir milyon ve üzeri evren için toplam ulaşılması gereken minimum anket sayısı Sekaran'a (2000: 95) göre 384'tür. Çalışma evreni dikkate alındığında ulaşılması gereken minimum sayı 226 olarak tespit edilmiştir. İlgili işletmeler ile görüşülerek anketlerin dağıtımı sağlanmış ve toplamda 386 adet değerlendirmeye alınabilir anket elde edilmiştir.

Araştırmada veri toplama aracı olarak anket tekniği kullanılmış olup anket formu üç bölümden oluşmaktadır. Anlekin ilk bölümünde katılımcıların demografik özelliklerine (yaş, cinsiyet, medeni durum, bulundukları işletmedeki çalışma süresi ve aylık gelir) ilişkin toplam 5 soru yer almaktadır. Anketin ikinci bölümü ise katılımcıların kişilik özelliklerini belirlemeye yönelik ifadeler içermektedir. Beş Faktör Kişilik Modelinin öğelerini ölçebilmek için bu araştırmada kullanılan ölçek; Jonh, Donahue ve Kentle (1991) tarafından geliştirilmiş olup 2009' da Gümüş tarafından Türkçe'ye uyarlanmıştır. Büyük Beşli Kişilik Envanteri (Big Five İnvantory-BFI) ölçeği 66 
dışa dönüklük, uyumluluk, sorumluluk, nevrotiklik ve açıklık olmak üzere beş boyut ve toplamda 44 ifadeden oluşmaktadır. Anketin üçüncü ve son bölümünde ise katılımcıların zaman hırsızlığ eğilimlerini ölçmeye yönelik ifadeleri kapsayan zaman hırsızlığı ölçeği kullanılmıştır. Kullanılan ölçek Brock, Martin ve Buckley (2013) tarafından geliştirilmiş olup Babadağ ve Kerse (2019) tarafından Türkçe' ye uyarlanmıştır. Anket formunun üçüncü kısmını oluşturan zaman hırsızlığ1 ölçeği toplamda 15 ifadeden oluşmaktadır. İfadeler, geleneksel zaman hırsızlığı, teknolojik zaman hırsızlığı ve sosyal zaman hırsızlığı olmak üzere üç boyutta toplanmıştır. Anket formunun ikinci ve üçüncü bölümlerinde 5'li Likert (1=Kesinlikle Katılmıyorum, 2=katılmıyorum, 3=Kısmen Katılıyorum, 4=Katılıyorum, 5=Kesinlikle Katılıyorum )kullanılmıştır. Araştırma kapsamında toplanan verilerin analizleri için IBM SPSS Version 23 kullanılmıştır.

\section{BULGULAR}

Araştırmanın bu bölümünde; çalışanların demografik özelliklere ilişkin frekans analizlerine, araştırma kapsamında kullanılan ölçeklere yönelik güvenirlik ve ölçeklerin yapı geçerliliği analizlerine, otel işgörenlerinin kişilik özellikleri ile zaman hırsızlığı davranışı arasındaki ilişki ve etki düzeylerini ölçmeye yönelik analizlere yer verilmiştir.

\subsection{Araştırmaya Katılanların Demografik Özellikleri}

Çalışma kapsamında toplanması gereken veriler anket aracılı̆̆ı ile elde edilmiştir. Anketlerin ilk kısmını oluşturan ve katılımcıların demografik özelliklerini belirlemek amacıyla yöneltilen ifadelere, katılımcılar tarafından verilen yanıtlar ele alınmıştır. Gerekli analizler yapılarak toplamda 386 katılımcının, yaş, cinsiyet, medeni durum, öğrenim durumu, aylık gelir ve ilgili işletmedeki çalışma süresine ilişkin tespitlerde bulunulmuş, frekans ve yüzde dağılımlarına ulaşılmıştır. Elde edilen bulgular Tablo 1' de gösterilmektedir.

Tablo 1: Katılımcıların Demografik Özellikleri $(\mathrm{N}=386)$

\begin{tabular}{|c|c|c|}
\hline DEMOGRAFİK ÖZELLİKLER & Frekans & Yüzde \\
\hline \multicolumn{3}{|l|}{ Cinsiyet } \\
\hline Kadın & 243 & 63,0 \\
\hline Erkek & 143 & 37,0 \\
\hline \multicolumn{3}{|l|}{ Medeni Durum } \\
\hline Evli & 239 & 61,9 \\
\hline Bekar & 147 & 38,1 \\
\hline \multicolumn{3}{|l|}{ Yaş } \\
\hline $18-20$ & 32 & 8,3 \\
\hline $21-30$ & 210 & 54,4 \\
\hline $31-40$ & 118 & 30,6 \\
\hline 41 ve üzeri & 26 & 6,7 \\
\hline \multicolumn{3}{|l|}{ Öğrenim Durumu } \\
\hline İlköğretim & 6 & 1,6 \\
\hline Ortaöğretim & 54 & 14,0 \\
\hline Önlisans & 77 & 19,9 \\
\hline Lisans & 192 & 49,7 \\
\hline Lisansüstü & 57 & 14,8 \\
\hline \multicolumn{3}{|l|}{ Çalışma Süresi } \\
\hline 1 yıldan az & 124 & 32,1 \\
\hline 1-3 yıl arası & 93 & 24,1 \\
\hline 4-6 yıl aras1 & 84 & 21,8 \\
\hline 7-9 yil arası & 49 & 12,7 \\
\hline 10 yıl ve üzeri & 36 & 9,3 \\
\hline \multicolumn{3}{|l|}{ Aylık Gelir } \\
\hline 2324 TL ve alt1 & 101 & 26,2 \\
\hline $2325-4000 \mathrm{TL}$ & 138 & 35,8 \\
\hline $4001-6000$ & 86 & 22,3 \\
\hline 6000 TL ve üzeri & 61 & 15,8 \\
\hline
\end{tabular}


Araştırmaya katılan işgörenlerin demografik özelliklerine ait bulguların yer aldığı Tablo 1 incelendiğinde; öncelikle katılımcıların \% 63' ünü kadınların, \% 37'sini ise erkeklerin oluşturduğunu söyleyebiliriz. Bu yüzdelere tekabül eden rakamlar ise kadınlarda 243 kişi iken erkeklerde bu sayı 143' dür. Elde edilen sayılardan hareketle kadın katılımcıların erkek katılımcılara nazaran daha fazla olduğunu söylemek mümkündür. Bu durum kadın işgörenlerin yine erkek işgörenlere kıyasla sayıca fazla olduğunu göstermektedir. Ortaya çıkan bu bulgu; kadınların istihdam alanında varlıklarını sürdürdüklerini ve erkeklere nazaran iş hayatında daha çok yer aldıklarını ortaya koymaktadır. Katılımcıların medeni durumlarına ilişkin elde edilen dağılımda ise evli olanlar \% 63,9 (239 kişi) iken bekar olanlar \%38,9 (147 kişi) şeklindedir. Bu dağılım evli olan katılımcı sayısının bekar olan katılımcı sayısına kıyasla daha çok olduğu anlamına gelmektedir. Katılımcıların demografik özellikleri kapsamında yer alan ve hangi yaş gruplarına dahil olduklarına dair ifadelerin analiz sonuçları incelendiğinde \% 54, 4 ile en çok katılım sağlayan yaş grubunun 21-30 (210 kişi) yaş grubu olduğu görülmektedir. En çok katılım sağlayan yaş grubunun 21-30 aralığında olmasının nedeni, turizm sektörünün tercih ettiği ya da turizm sektörünü tercih edenlerin daha dinamik ve genç olmaları şeklinde yorumlanabilir. Devamında Tablo'da katılımcıların öğrenim durumlarına ilişkin sonuçlar incelendiğinde \% 49,7 (192 kişi) ile çoğunluğun lisan öğrenimine sahip olduğu bulgusuna ulaşılmaktadır. Oranlar incelendiğinde, turizm işletmelerinin daha nitelikli ve öğrenim düzeyi yüksek kişileri tercih ettiği sonucuna ulaşılmaktadır.

Katılımcıların işletmelerdeki çalışma sürelerine ilişkin bulgular incelendiğinde ise dağılımlar arasında büyük farklar olmadığı göze çarpmaktadır. Bu dağılımlara göre çalışma süresi bir yıldan az olan katılımcı yüzdesi \%32,1 (124 kişi), çalışma süresi 1-3 yıl arasında olan katılım yüzdesi \% 24,1 (93 kişi), çalışma süresi 4-6 yıl arasında olanların \% 21,8 (84 kişi), çalışma süresi 7-9 yıl aralığında olanlar , \%12,7 (49 kişi), çalışma süresi 10 yıl ve üzeri olanlar ise \%9,3 (16 kişi) şeklindedir. Elde edilen bu bulgulara göre işletmelerde işgören kişilerin çoğunluğu 1 yıldan az süreyle istihdam etmektedir. Oranlar sektörde personel devir hızının yüksek olduğunu göstermektedir. İşgörenlerin aynı işletmede uzun süre kalmamaları durumunu ifade eden personel devir hızı yüksekliği, niteliği ve hizmet kalitesini olumsuz yönde etkilemektedir. Zira sürekli iş yeri değiştiren personel adaptasyonda problem yaşayacağı gibi verim ve etkinlik konusunda da olumsuz yönelim gösterecektir. Demografik özellikler kapsaminda incelen son boyut işgörenlerin aylık gelirleridir. Tabloda yer alan bulgular 1şığında katılımcıların \%35,8' nin (138 kişi) 2325-4000 TL arasında gelire sahip oldukları, \% 26,2' sinin (101 kişi) 2324 TL ve altı gelire sahip oldukları, \% 22,3' ünün (86 kişi) 4001-6000 aralığında bir gelire sahip oldukları , \% 15,8'inin ise 6000 TL ve üzeri gelire sahip oldukları anlaşılmaktadır. Veriler incelendiğinde işgörenlerin büyük bir kısmının 2325-4000 TL arasında gelir ile istihdam gösterdikleri söylenebilir.

\section{2. Ölçeklere İlişkin Güvenirlik Analizleri}

Cronbach Alpha değeri sosyal bilimler alanında yapılan araştırmalar kapsamında kullanılan ölçeklerin güvenilirliğini ifade eden bir kat sayıdır. Literatüre göre Cronbach Alpha kat sayısının $0,40^{\prime}$ in altında olması durumu güvenilir olmadığı anlamına gelmektedir. Bu değerin 0,40 ile 0,60 arasında bir değer alması düşük güvenilirlik anlamına gelmektedir. Cronbach Alpha kat sayısının 0,60 ile 0,80 değer aralığında olması ise güvenilir olarak kabul edilirken, 0,80 ile 1,00 arasında bir değer alması durumunda yüksek güvenilirlik anlamı taşıdığı ifade edilmektedir (Yazıcıŏ̆lu ve Erdoğan 2011). Araştırma kapsamında yer alan kişilik özellikleri ve zaman hırsızlığı ölçekleri ve alt boyutlarına ilişkin tespit edilen Cronbach Alpha değerleri Tablo 2’ de yer almaktadır.

Tablo 2. Ölçeklere ilişkin güvenirlik analizleri

\begin{tabular}{|l|c|c|}
\hline Ölçekler ile Alt Boyutları & Cronbach Alpha Değeri & Ölçekte Yer Alan Madde Sayısı \\
\hline Kişilik özellikleri & 0,775 & 33 \\
\hline Dişadönüklük & 0,700 & 4 \\
\hline Uyumluluk & 0,850 & 7 \\
\hline
\end{tabular}




\begin{tabular}{|l|c|c|}
\hline Sorumluluk & 0,720 & 6 \\
\hline Nevrotiklik & 0,700 & 7 \\
\hline Açılık & 0,743 & 9 \\
\hline Zaman hırsızlığı & 0,859 & 15 \\
\hline Geleneksel & 0,807 & 7 \\
\hline Teknolojik & 0,827 & 4 \\
\hline Sosyal & 0,806 & 4 \\
\hline
\end{tabular}

Tablo 2 incelendiği taktirde kişilik özellikleri, zaman hırsızlığı ve bu değişkenlerin alt boyutlarına ilişkin Cronbach Alpha kat sayı değerleri görülmektedir. Değişkenlerin ve alt boyutlarının Cronbach Alpha değerlerinin genel itibatıyla 0,70 üzerinde olduğu tespit edilmiştir. Elde edilen bu saptamalar araştırma kapsamında kullanılan ölçeklerin güvenilirlik seviyesinin yeterli düzeyde olduğu anlamına gelmektedir.

\subsection{Faktör Analizleri}

Araştırmanın evrenini temsil eden örneklem büyüklüğünün faktör analizi yeterliliğini belirlemek için Kaiser-Meyer-Olkin (KMO) değeri dikkate alınmaktadır. Ölçekte yer alan maddeler arasında anlamlı korelasyonlar olup olmadığını belirlemek için ise Bartlett Küresellik testi sonuçları dikkate alınmaktadır Literatürde KMO değerinin genellikle ,50'nin üzerinde olması tavsiye edilmektedir. (Çokluk vd., 2012: 207). Aşağıda Kişilik Özellikleri Ölçeği ve Zaman Hırsızlığı Ölçeğine yönelik faktör analizleri sonuçları yer almaktadır.

\subsubsection{Kişilik Özellikleri Ölçeğinin Faktör Analizi Sonuçları}

Kişilik özellikleri ölçeğine yönelik yapılan faktör analizinde KMO değeri 0,593 olarak hesaplanmıştır. Ayrıca $(\mathrm{p}<, 001)$ anlamlılık düzeyinde Bartlett Küresellik testi sonucu ise 294 olarak bulunmuştur. Kişilik özellikleri ölçeğine yönelik açılanan toplam varyans ise \%53,999 olarak hesaplanmıştır. Ölçekte yer alan maddelerin faktör yükleri ise Varimax dik döndürme yöntemi kullanılarak elde edilmiştir.

Tablo 3: Kişilik Özelliklerinin Faktör Analizi Sonuçları

\begin{tabular}{|c|c|c|}
\hline KİŞİLİK ÖZELLİKLERİ ÖLÇEĞİ & $\begin{array}{c}\text { Faktör } \\
\text { Yükü }\end{array}$ & $\begin{array}{c}\text { Açılanan } \\
\text { varyans }\end{array}$ \\
\hline Dişadönüklük & & 23,985 \\
\hline Konuşkan biriyim. &, 553 & \\
\hline Çekingen biriyim. & 659 & \\
\hline Enerji doluyumdur. & 442 & \\
\hline Sessiz biriyim. & 694 & \\
\hline Uyumluluk & & 9,160 \\
\hline Başkalarının hatalarını bulmaya eğilimliyimdir. &, 570 & \\
\hline Bazen diğer insanlara kaba davranırım. & ,709 & \\
\hline Yardımsever, fedakâr biriyim. &, 562 & \\
\hline Affedici bir yapım var. & 304 & \\
\hline Güvenilir biriyim. & 744 & \\
\hline Soğukkanlı biriyim. &, 538 & \\
\hline Herkese karşı saygılıyımdır. & 681 & \\
\hline Sorumluluk & & 7,707 \\
\hline Bir işi kusursuz yaparım. & 395 & \\
\hline Bazen dikkatsizimdir. &, 521 & \\
\hline Güvenilir bir işgörenimdir. & 762 & \\
\hline Düzensiz dağınık biriyim. & 466 & \\
\hline Tembel biriyim. & 465 & \\
\hline Yaptığım işleri etkin, verimli bir şekilde yaparım. & ,396 & \\
\hline
\end{tabular}




\begin{tabular}{|l|l|l|}
\hline Nevrotiklik & 7,700 \\
\hline Depresif, hüzünlü biriyim. &, 620 & \\
\hline Rahat biriyim ve strese girmem. &, 628 & \\
\hline Bazen gergin olabilirim. &, 506 & \\
\hline Endişeli biriyim. &, 609 & \\
\hline Duygusal olarak istikrarlı biriyim. &, 387 & \\
\hline Bazen karamsar olabiliyorum. &, 438 & \\
\hline Kolay sinirlenirim. &, 678 & \\
\hline Açılık & $, 6,447$ \\
\hline Orijinal, yeni fikirlere açı biriyim. &, 658 & \\
\hline Farklı şeylere ilgi duyarım. &, 499 & \\
\hline Zeki biriyim. &, 639 & \\
\hline Hayal gücüm yüksektir. &, 600 & \\
\hline Yaratıcı biriyim. &, 423 \\
\hline Sanatsal ve estetik şeyler benim için önemlidir. &, 676 \\
\hline Rutin işleri yapmayı severim. &, 515 & \\
\hline Fikirlerle oynamayı ve benim için ne anlama geldiklerini düşünmeyi severim. &, 539 \\
\hline Sanata karşı pek ilgim yoktur. &, 760 \\
\hline Toplam & & \\
\hline
\end{tabular}

Kişilik özellikleri ölçeğinin ilk boyutu olan "Dışa dönüklük" boyutu kapsamında yer alan toplam sekiz ifadenin dördü faktör yükü belirlenen sınırın dişında olduğundan analizlere dahil edilmemiştir. Bu ifadeler; "Diğer insanları heveslendiririm", "girişken biriyim", "utangaç ve çekimser biriyim", "dışa dönük sosyal biriyim". Aynı şekilde kişilik özelliklerinin bir diğer alt boyutu olan "Uyumluluk" orjinalinde dokuz ifadeden oluşmaktadır. Bu ifadelerden, " Başkaları ile ağız dalaşına girerim" ve "iş arkadaşlarım ile çalışmayı severim" faktör yükü kabul edilebilir sınırda olmadığından analizlere dahil edilmeyip ölçekten çıkarılmıştır. Kişilik özelliklerinin "sorumluluk" alt boyutuna dahil olan toplam dokuz ifade vardır. Bu ifadelerden, "Bir işi bitirene kadar bırakmam", "Plan yapar ve yaptığım planları uygularım", "Dikkatim çabuk dağılır" ifadeleri kullanılabilir faktör yüküne sahip olmadığından ölçekten çıkarılmıştır. Kişilik özellikleri ölçeğinin alt boyutlarından olan "Nevrotiklik" toplam 8 ifadeden oluşmakta olup, bu ifadelerden "Gergin ortamlarda sakin kalabilirim" faktör yükü uygun sınırlarda olmadığından ölçekten çıkarılıp analizlere dahil edilmemiştir. Kişilik özellikleri ölçeğinin son boyutu olan "Açıklık" ise 10 ifadeden oluşmaktadır. Bu ifadelerinde faktör yükleri tespit edilerek, kullanılabilir sınırda olmayan "Resim, müzik ve edebiyatla ilgiliyimdir" ifadesi ölçekten çıkarılmış analizlere dahil edilmemiştir. Sonuç olarak kişilik özellikleri ölçeğinde yer alan maddelerden, belirlenen faktör yükü değerinin altında olan 12 madde çıkarılmıştır. Toplam 44 ifadeden oluşan kişilik özellikleri ölçeğinin faktör yükü uygun olan 33 maddesi kullanılmıştır.

\subsubsection{Zaman Hırsızlığı Ölçeğinin Faktör Analizi Sonuçlarına İlişkin Bulgular}

Kişilik özellikleri ölçeğine yönelik yapılan faktör analizinde KMO değeri 0,709 olarak hesaplanmıştır. Ayrıca ( $<<, 001)$ anlamlılık düzeyinde Bartlett Küresellik testi sonucu ise 481 olarak bulunmuştur. Kişilik özellikleri ölçeğine yönelik açılanan toplam varyans ise \%60,468 olarak hesaplanmıştır. Ölçekte yer alan maddelerin faktör yükleri ise Varimax dik döndürme yöntemi kullanılarak elde edilmiştir.

Tablo 4: Zaman Hırsızlı̆̆ı Ölçeğinin Faktör Analizi Sonuçları

\begin{tabular}{|l|l|l|}
\hline ZAMAN HIRSIZLIĞI ÖLÇEĞİ & $\begin{array}{l}\text { Faktör } \\
\text { Yükü }\end{array}$ & $\begin{array}{l}\text { Açıklanan } \\
\text { varyans }\end{array}$ \\
\hline Geleneksel Boyut & & 27,862 \\
\hline $\begin{array}{l}\text { Yöneticime/iş arkadaşlarıma erken bitirebileceğimi bildiğim halde verilen işin daha } \\
\text { uzun süreceğini söylerim. }\end{array}$ &, 629 & \\
\hline $\begin{array}{l}\text { İşe gitmek istemediğimde hasta olmasam bile işyerini arayıp hasta olduğumu } \\
\text { söylerim. }\end{array}$ &, 664 & \\
\hline Eğer yöneticim gün içinde işten erken çıarsa ben de işten erken çıkarım. &, 659 & \\
\hline
\end{tabular}




\begin{tabular}{|l|l|l|}
\hline İşime yapabileceğimi bildiğimden daha az çaba harcıyorum. &, 708 & \\
\hline İşteyken hayal kuruyorum (hayallere dalıyorum). &, 637 & \\
\hline Mesai saatleri içerisinde kitap ve dergi okumak için mola veririm. &, 597 & \\
\hline Bir işi (projeyi) mesaiden 20 dakika önce bitirirsem yeni bir işe (projeye) başlamam. &, 667 & 19,031 \\
\hline Teknolojik Boyut & & \\
\hline İş yerinde işle ilgisi olmayan e-mail gönderirim. &, 641 & \\
\hline İş saatlerinde internette işle ilgili olmayan nedenlerle de zaman geçiririm &, 819 & \\
\hline İş yerinde işle ilgisi olmayan e-maillerimi kontrol ederim. &, 768 & \\
\hline İş yerinde işle ilgisi olmayan e-mailler alırım. &, 644 & \\
\hline Sosyal Boyutu & & 13,575 \\
\hline $\begin{array}{l}\text { İşs saatleri içerisinde iş arkadaşlarımla dedikodu yapar veya aileleri hakkında } \\
\text { konuşurum }\end{array}$ &, 677 & \\
\hline İşle ilgili olmayan konular hakkında yöneticimle konuşmak için işime ara veririm. &, 614 & \\
\hline $\begin{array}{l}\text { İşsaatlerinde iş arkadaşları veya müşsterilerle ofis dışında veya içerisinde boş zaman } \\
\text { aktiviteleri (Öğle yemeğine, bir şeyler içmeye veya akşam yemeğine gitmek gibi) için } \\
\text { zaman harcarım. }\end{array}$ &, 519 & \\
\hline İş yerinde kişisel telefon aramalarına cevap veririm. &, 397 & \\
\hline Toplam & & 60,468 \\
\hline
\end{tabular}

Tablo 4'te yer alan zaman hırsızlığı ve boyutlarına ilişkin ifadelerin faktör yükleri ölçülmüştür. Herhangi bir ifade de faktör yükünün kabul edilebilir sınırların dışında olmadığı sonucuna ulaşılmıştır. Bu kapsamda zaman hırsızlığı ve alt boyutlarına ilişkin ifadeler ölçekten çıkarılmayıp analizlere dahil edilmiştir.

Araştırma kapsamında kullanılan ölçeklerin güvenilirlik ve geçerliliği test edildikten sonra yapılacak olan analizlerin ön koşulu olan normallik testi yapılmıştır. Yapılan normallik testi sonucunda ifadelerin anlam düzeylerinin $0,5^{\prime}$ den küçük olması durumunda verilerin normal dağılım göstermedikleri anlaşılmaktadır. Konu ile ilgili Fidell ve Tabachnick' in (2001) ifadeleri göz önünde bulundurulması durumunda; çarpıklık ve basıklık değerlerinin $+1,5$ ile $-1,5$ aralığında olması normal dağılım gösterdiği anlamını taşımaktadır (Akt. Özer ve Güllüce, 2019). Yapılan normallik testi sonucu verilerin buna göre normal dağildığı sonucuna varılmış olup parametrik testler uygulanmıştır.

\subsection{Korelasyon Analizleri}

Çalışma kapsamında değişkenlerin normal dağılıma uygunluk testleri SPSS veri analiz programı ile yapılmış olup, sonraki aşamalar (korelasyon ve regresyon analizleri) için ön koşul sağlanmıştır. Normal dağılım gösterdikleri anlaşılan değişkenlerin arasındaki ilişkiyi belirlemeye yönelik korelasyon analizi yapılmıştır. Korelasyon analiz sonuçlarına göre elde edilen katsayı $\mathrm{r}$ harfi ile ifade edilir ve $r$ değeri; -1 ile +1 aralığında olmalıdır. $R$ değeri -1' e yakın ise değişkenler arasında negatif yönlü bir ilişki mevcuttur. $R$ değeri $+1^{\prime}$ e yakın ise değişkenler arasında pozitif yönlü bir ilişki mevcuttur. $R$ değerinin sıfıra yakın değerler alması durumunda ise değişkenler arası bir ilişki söz konusu değildir (Çolak, 2014: 6-7).

Tablo 5’ de Kişilik özellikleri ve alt boyutları ile zaman hırsızlığı ve alt boyutları arasındaki ilişkiye yönelik Korelasyon Analizi sonuçları yer almaktadır.

Tablo 5: Kişilik Özellikleri ile Zaman hırsızlığı arasındaki ilişkiye yönelik Korelasyon Analizi Sonuçları $(n=386)$.

\begin{tabular}{|c|l|c|c|c|c|c|c|c|c|c|c|}
\hline & Faktör & $\mathbf{1}$ & $\mathbf{2}$ & $\mathbf{3}$ & $\mathbf{4}$ & $\mathbf{5}$ & $\mathbf{6}$ & $\mathbf{7}$ & $\mathbf{8}$ & $\mathbf{9}$ & $\mathbf{1 0}$ \\
\hline $\mathbf{1}$ & Kişilik Özellikleri & 1 & & & & & & & & \\
\hline $\mathbf{2}$ & Dişadönüklük &, $521^{* *}$ & 1 & & & & & & & \\
\hline $\mathbf{3}$ & Uyumluluk &, $713^{* *}$ &, $154^{* *}$ & 1 & & & & & & & \\
\hline $\mathbf{4}$ & Sorumluluk &, $572^{* *}$ &, $315^{* *}$ &, $204^{* *}$ & 1 & & & & & & \\
\hline $\mathbf{5}$ & Nevrotiklik &, $762^{* *}$ &, $372^{* *}$ &, $381^{* *}$ &, $390^{* *}$ & 1 & & & & & \\
\hline $\mathbf{6}$ & Açıklık &, $782^{* *}$ &, $257^{* *}$ &, $567^{* *}$ &, $253^{* *}$ &, $462^{* *}$ & 1 & & & & \\
\hline
\end{tabular}




\begin{tabular}{|c|l|c|c|c|c|c|c|c|c|c|c|}
\hline $\mathbf{7}$ & Zaman Hirsılı̆̆1 &, 080 &, $125^{*}$ &, 038 &, 061 &, $132^{* *}$ &, 013 & 1 & & \\
\hline $\mathbf{8}$ & Geleneksel &, 055 &, $147^{* *}$ &, 052 &, 094 &, $145^{* *}$ &, 053 &, $862^{* *}$ & 1 & \\
\hline $\mathbf{9}$ & Teknolojik &, 038 &, $102^{*}$ &, 021 &, 021 &, 083 &, 029 &, $895^{* *}$ &, $639^{* *}$ & 1 & \\
\hline $\mathbf{1 0}$ & Sosyal &, $167^{* *}$ &, 086 &, $219^{* *}$ &, 029 &, $162^{* *}$ &, 097 &, $814^{* *}$ &, $528^{* *}$ &, $699^{* *}$ & 1 \\
\hline
\end{tabular}

Tablo 5' de yer alan veriler doğrultusunda, kişilik özellikleri ile zaman hırsızlığının (sosyal boyut hariç) tamamı arasında anlamlı bir ilişkiye rastlanmamıştır. Ancak kişilik özellikleri ile zaman hırsızlığının sosyal boyutu arasında 0,01 anlamlılık düzeyinde pozitif yönlü bir ilişkiye rastlanmıştır. Kişilik özelliklerinin dışadönüklük boyutu ile zaman hırsızlığının tamamı arasındaki ilişkiye yönelik veriler incelendiğinde, 0,05 anlamlılık düzeyinde pozitif yönlü orta düzeyde anlamlı bir ilişki göze çarpmaktadır. Yine dişadönüklük boyutu ile zaman hırsızlığının alt boyutları arasındaki ilişki düzeylerine bakacak olursak; dışadönüklük ile geleneksel alt boyut arasında 0,01 anlamlılık düzeyinde pozitif yönlü bir ilişki tespit edilirken, dişadönüklük ile zaman hırsızlığının teknolojik alt boyutu arasında 0,05 anlamlılık düzeyinde pozitif yönlü orta seviyede bir ilişki tespit edilmektedir. Dışadönüklük alt boyut ile sosyal alt boyut arasında ise istatistiksel olarak anlamlı bir ilişki saptanmamıştır.

Kişilik özelliklerinin bir diğer alt boyutu olan uyumluluk ile zaman hırsızlığının tamamı arasında anlamlı bir ilişkiye rastlanmamıştır. Yine aynı şekilde uyumluluk alt boyutu ile geleneksel ve teknolojik alt boyutlar arasında da anlamlı bir ilişki bulunmamışken, sosyal alt boyut ile uyumluluk arasında 0,01 düzeyinde pozitif yönlü anlamlı bir ilişki saptanıştır. Bir diğer alt boyut olan sorumluk ile zaman hırsızlığının tamamı arasında anlamlı bir ilişkiye rastlanmamıştır. Sorumluluk ile zaman hırsızlı̆̆ının alt boyutları arasındaki ilişkiyi değerlendirecek olursak; geleneksel, teknolojik ve sosyal alt boyutlar ile anlamlı ilişkisi bir ilişkisinin bulunmadığı ortaya çıkmaktadır. Kişilik özelliklerinin bir diğer alt boyutu nevrotiklik ile zaman hırsızlığının tamamı arasında 0,01 düzeyinde pozitif yönlü anlamlı bir ilişki tespit edilmiştir. Aynı şekilde nevrotiklik alt boyutu ile gelenesel ve sosyal boyut arasında da 0,01 düzeyinde pozitif yönlü bir anlamlılık saptanmıştır ancak nevrotiklik ile teknolojik alt boyut arasında anlamlı bir ilişki bulunamamıştır. Son olarak açıklık boyutu ile zaman hırsızlığının tamamı ve alt boyutları arasında anlamlı bir ilişkiye rastlanmamıştır. Uygulanan analizler sonucunda değişkenler arasındaki ilişkilere yönelik saptamalar göz önünde bulundurularak (H1) hipotezinin desteklenmediği anlaşılmaktadır.

\subsection{Regresyon Analizleri}

Değişkenler arası istatistiksel bağıntıyı ve etkiyi analiz etmek için basit ve çoklu regresyon analizleri kullanılmakta olup, iki değişken olduğu durumlarda bağımlı değişken ile bağımsız değişken ya da değişkenler arasında uygulanmaktadır. Bu analizlerin uygulanabilmesi için öncelikle verilerin normal dağılım göstermeleri, bağımsız değişkenlerinde aynı şeklide normal dağılım göstermesi gerekmektedir. Bu durumların yerine getirilmesi regresyon analizlerinin de ön koşuludur. Normal dağılım göstermiş olan sayısal bir değişken ile aralarında ilişki olan bir diğer normal dağılım göstermiş değişkeni tahmin için "basit doğrusal regresyon" (simple linear regression) kullanılmaktadır. Birden fazla değişkenden faydalanılarak, bir değişken tahmini için ise "çoklu regresyon analizi" (multiple linear regression) tercih edilmektedir ( Kılıç, 2013: 2).

Çalışma kapsamında normal dağılımları ispatlanmış ve aralarındaki ilişki de korelasyon analizleri ile tespit edilmiş olan değişkenlerin aralarındaki etkiyi ölçmek amacı ile basit doğrusal regresyon ve çoklu regresyon analizleri uygulanmıştır.

Tablo 6’ da işgörenlerin kişilik özelliklerinin zaman hırsızlığı eğilimleri üzerine etkisini ölçmek amacıyla yapılmış basit doğrusal regresyon analizlerine ait bulgular yer almaktadır. 
Tablo 6: Kişilik Özelliklerinin Zaman Hırsızlığı Eğilimleri Üzerindeki Etkisine Yönelik Regresyon Analizi Sonuçları $(\mathrm{N}=386)$

\begin{tabular}{|c|c|c|c|c|c|}
\hline Model & \multicolumn{2}{|c|}{$\begin{array}{c}\text { Standardize Edilmemiş } \\
\text { Değişkenin Katsayısı }\end{array}$} & $\begin{array}{c}\text { Standardize Edilmiş } \\
\text { Değişkenin Kat Sayıs }\end{array}$ & $\begin{array}{c}\text { Anlam } \\
\text { Düzeyi } \\
\text { (p) }\end{array}$ \\
\hline Sabit & B & Std. hata & Beta & \multirow{2}{*}{, 0012} \\
\hline Kişilik Özellikleri & 1,147 &, 394 &, 154 & 3,056 &, 002 \\
\hline
\end{tabular}

Bă̆ımlı değişken: Zaman hırsızlı̆̆

$\mathbf{R}^{2}$ : ,024; Hatanın standart sapmasi; 80056

Kişilik özelliklerinin zaman hırsızlı̆̆ı üzerindeki etkisinin ölçüldüğü basit doğrusal regresyon analizleri kapsamında bağımlı değişken zaman hırsızlığı iken; bağımsız değişken ise kişilik özellikleridir. Determinasyon kat sayı değeri $\left(\mathrm{R}^{2}\right) 0$ ile +1 arasılığında bir değer almalıdır. Analizler sonucunda ise $\mathrm{R}^{2}$ değeri $(, 024)$ olarak tespit edilmiştir. Şöyle ki, zaman hırsızlığındaki bir birimlik değişimin yaklaşık \%3” lük kısmını kişilik özelliklerinin oluşturduğu söylenebilir. Bunun yanı sıra anlamlılık seviyesi incelenecek olursa, $(\mathrm{P}<0,05)$ olması kişilik özellikleri değişkeninin zaman hırsızlığı değişkeni üzerinde anlamlı belirleyici bir faktör olduğunu göstermektedir. Regresyon analiz sonuçlarının verildiği tablo $6^{\prime}$ da yer alan beta değeri $(, 154)$ ise kişilik özellikleri değişkeninin zaman hırsızlığı değişkeni üzerindeki pozitif yönlü bir etki olduğunu ortaya koymaktadır. Bu durum çalışmanın hedef grubu olan işgörenlerin kişilik özelliklerinin zaman hırsızlığı eğilimlerini anlamlı bir şekilde etkilediği sonucunu vermektedir.

Değişkenlerin etki düzeylerine yönelik yapılan saptamalar çalışma kapsamında geliştirilmiş olan (H2) hipotezinin desteklendiğini göstermektedir.

Kişilik özelliklerinin alt boyutlarının zaman hırsızlığı üzerindeki etkisini ölçmek için çalışma kapsamında çoklu regresyon analizi yapılıştır. Analiz sonucunda elde edilen sonuçlar Tablo 6’ da sunulmaktadir.

Tablo 7: Kişilik özelliklerinin alt boyutlarının Zaman Hırsızlığı üzerindeki etkisine yönelik çoklu regresyon analizi sonuçları (386)

\begin{tabular}{|c|c|c|c|c|c|}
\hline \multirow[b]{2}{*}{ Model } & \multicolumn{2}{|c|}{$\begin{array}{c}\begin{array}{l}\text { Standardize edilmemiş değişkenin } \\
\text { katsayıs }\end{array} \\
\end{array}$} & \multirow{2}{*}{$\begin{array}{l}\begin{array}{l}\text { Standardize edilmiş } \\
\text { değişkenin katsayısı }\end{array} \\
\text { Beta }\end{array}$} & \multirow{2}{*}{$\mathbf{t}$} & \multirow{2}{*}{$\begin{array}{c}\text { Anlam } \\
\text { düzeyi(p) } \\
(\mathrm{p}<0,05)\end{array}$} \\
\hline & B & Std. Hata & & & \\
\hline Sabit & 1,308 & ,405 & & 3,232 & ,001 \\
\hline Dişadönüklük & 122 & ,081 & ,084 & 1,514 & 131 \\
\hline Uyumluluk & ,066 & ,093 & ,046 & 709 & ,478 \\
\hline Sorumluluk &,- 026 & ,098 &,- 015 &,- 264 & 792 \\
\hline Nevrotiklik & ,324 & ,095 & ,213 & 3,407 & ,001 \\
\hline Açıklık &,- 171 & 111 & -,101 & $-1,536$ & 125 \\
\hline
\end{tabular}

Bağımlı Değişken: Zaman Hırsızlığ1

$\mathbf{R}^{2}$ : ,054; Hatanın standart sapması: ,79231

Tablo 7 incelendiğinde kişilik özelliklerinin alt boyutları olan; dışadönüklük, sorumluluk, uyumluluk, nevrotiklik ve açıklık değişkenlerinin zaman hırsızlığı eğilimleri üzerindeki etkisinin ne yönde olduğu anlaşılmaktadır. Çoklu regresyon analizinde bağımlı değişken zaman hırsızlığı olarak kabul edilirken kişilik özelliklerinin alt boyutları ise bağımsız değişken olarak kabul edilmektedir. Analizler sonucunda $\mathrm{R}^{2}$ değeri $(0,54)$ olarak tespit edilmiştir. Bu değer zaman hırsızlığ1 değişkenindeki bir birimlik değişimin yaklaşık olarak \% 6' sını kişilik özelliklerinin alt boyutları olan, 
dışadönüklük, sorumluluk, uyumluluk, nevrotiklik ve açıklık oluşturmaktadır. Regresyon analizinden elde edilen bulgulardan hareketle kişilik özelliklerinin alt boyutlarından olan; dışadönüklük, uyumluluk, sorumluluk ve açıklık değişkenlerinin zaman hırsızlığı eğilimleri üzerinde anlamlı belirleyiciler olmadığı anlaşılmaktadır. Ancak kişilik özellikleri alt boyutu olan nevrotiklik değişkeninin zaman hırsızlığı değişkeni üzerinde anlamlı bir etkiye $(p<0,05)$ sahip olduğu saptanmıştır. Tabloda verilen beta değerleri incelendiğinde ise nevrotiklik alt boyutunun zaman hırsızlığ1 üzerinde pozitif yönlü bir etkiye sahip olduğu görülmektedir. Bu durum işgörenlerin nevrotiklik özelliği güçlendikçe zaman hırsızlığı eğilimi de artış gösterdiği anlamına gelmektedir.

\section{SONUÇ}

Zamanın önemini kavramış kişiler, bireysel faydanın dışında üyesi oldukları toplumlar için de fayda sağlamaktadırlar. Nitekim, örgütsel yaşamda ve beşerî ilişkilerde zaman yönetiminin bilinci ile hareket edilmesi, verimlilik ve etkilik oranlarını artırmakla kalmayıp günümüz şartlarında mevcut olan hızlı veri akışına da ayak uydurularak üstün ayrıcalıklar elde edilmesini sağlamaktadır. Etkin ve verimli kullanılan zaman ayrıca gelişmişlik olarak da toplumları diğerlerinden ayırt eden belirleyici bir unsurdur. Alan yazının taranması sonucu zaman kavramı ile ilgili elde edilen genel yarg1; tüketildiğinde geri getirilemeyen, insan yaşamının merkezi olan, kesin bir tanımlamaya sıkıştırmanın pek mümkün olmadığı, soyut bir ifade şeklindedir.

Kavramsal çerçevede irdelenen zaman hırsızlığı ifadesi genel anlamıyla; bireylerin yerine getirmeleri gereken görev ve sorumluluklarına ait zaman dilimlerinde başka işlerle uğraşmaları ya da işgörenlerin mesai saatleri içerisinde ve iş yerinde ihmalkarlık yaparak sosyal, teknolojik vb. fiiler sergilemeleri şeklindedir. İncelenen alanyazına göre elde edilen veriler ; işgörenlerin sergiledikleri zaman hırsızlığı davranışları görev ve sorumluluklarının ertelenmesi sonucunun yanında verimlilik ve performans kaybına neden olup örgütü ekonomik, sosyal ve prestij anlamında zarara uğrattığ1 şeklindedir.

İlgili alanyazında; kişilik özellikleri değişkenine ilişkin kavramsal yaklaşımlar incelenmesi sonucunda kişilik özelliklerinin genel olarak; insanları birbirlerinden ayıran duygu, düşünce, davranış biçimi, dış uyarımlara karşı gösterilen tepkiler, biyolojik kaynaklı veya sonradan öğrenilmiş tüm haller şeklinde ifade edildiği anlaşılmaktadır (Abdioğlu vd., 2015: 86).

Yapılan incelemeler zaman hırsızlığı konusu ile ilişkili yapılmış çalışmaların azlığına işaret etmektedir. Zaman hırsızlığ 1 davranışlarının sergilenmesi üzerinde etkili olan faktörlere değinilmiş çalışmalara ratlansa da kişilik özelliklerinin zaman hırsızlığı üzerinde nasıl bir etkisi olduğuna dair pek fazla araştırmanın olmadığı da elde edilen sonuçlar arasındadır.

Çalışmanın evreni olan TRA1 ve TRB2 bölgesinde faaliyet gösteren 4 ve 5 yıldızlı otellerdeki toplam işgören sayısını temsil edebilecek minumum sayı 226 olarak belirlenmiş iken, ilgili tesislerden 386 anket sayısına ulaşılmış ve sonrasında elde edilen veriler değerlendirmeye alınmıştır. Değiş̧kenler arasındaki ilişki ve etkiyi ölçmek için gerekli analiz ve testler yapılmıştır.

TRA1 ve TRB2 bölgelerinde faaliyet gösteren işletmelerden toplanan veriler doğrultusunda toplam 386 katılımcının demografik özelliklerine ilişkin birtakım sonuçlara ulaşılmıştır. Katılım gösteren kişilerden kadınların sayısı erkeklere oranla daha fazladır. 243 kadın katılımcıya karşın 143 erkek katılımcı mevcuttur. Elde edilen bu sonuç otel işletmelerinde kadın işgören sayısının arttığına işaret edip, iş hayatında kadınların da var olduğunun belirtisidir. Bu katılımcılar arasında 239 kişinin evli, 147 kişinin ise bekar olduğu bilgisi yine elde edilen sonuçlar arasındadır. Katılımcıların büyük kısmını; medeni durumu evli olanlardır. Ayrıca katılımcıların bağlı bulundukları işletmede çalışma sürelerine yönelik veriler de elde edilmiştir. Elde edilen verilere göre katılımcıların çoğunluğunun bulunduğu işletmede 1 yıldan az bir süreyle çalıştığ 1 tespit edilmiştir. Elde edilen bu sonuç sektörde personel devir hızının yüksek olduğu anlamına gelmektedir. Personel devir hızının yüksek olması; işletmelerde istihdam eden personelin kısa süreli çalışması anlamına gelmektedir. Katılımcıların demografik özelliklerinin analiz edildiği sürecin sonucunda ayrıca işgörenlerin 
çoğunluğunun eğitim seviyesinin lisans düzeyinde olduğu anlaşılmaktadır. Elde edilen bu sonuç, nitelikli personellerin istihdam edildiğinin işaretidir.

Kişilik özellikleri ile işgörenlerin zaman hırsızlığı eğilimleri arasındaki ilişkiye yönelik yapılan korelasyon analizlerinin sonucunda ise değişkenler arası ilişkilerin yönleri tespit edilmiştir. Kişilik özelliklerinin tamamı ile alt boyutları arasındaki ilişkiye yönelik yapılan korelasyon analizi sonucunda pozitif yönde anlamlı bir ilişki tespit edilmiştir. Benzer şekilde zaman hırsızlığı ve alt boyutları arasında da 0,01 düzeyinde anlamlı bir ilişki olduğu sonucuna ulaşılmıştır. Kişilik özellikleri ile zaman hırsızlığının alt boyutları arasındaki ilişkiye yönelik ulaşılan sonuç ise genel olarak bu değişkenler arasında anlamlı bir ilişki bulunmadığı yönündedir. Kişilik özellikleri ile zaman hırsızlığının geleneksel ve teknolojik alt boyutu ile arasında anlamlı bir ilişkiye rastlanmamışken, kişilik özellikleri ile zaman hırsızlığı alt boyutu olan sosyal boyut ile 0,05 düzeyinde pozitif anlamlı bir ilişkiye rastlanmıştır.

Kişilik özelliklerinin alt boyutları ile zaman hırsızlı̆̆ı arasındaki ilişki ise şu şekildedir; Dışadönüklük alt boyutu ile zaman hırsızlığının alt boyutları olan teknolojik ve geleneksel alt boyut arasında pozitif yönlü anlamlı bir ilişki tespit edilmiş iken, dışadönüklük alt boyutu ile sosyal alt boyut arasında anlamlı bir ilişkiye rastlanmamıştır. Bir başka ifade ile dışadönük kişilik yapısına sahip işgörenler teknolojik ve geleneksel anlamda zaman israfına daha yatkın olup sosyal zaman hırsızlığı konusunda ise bilakis daha dikkatlidirler. Elde edilen bu sonuç daha önce konu ile ilgili Brock Baskin vd. (2017) tarafından yürütülmüş olan çalışmanın sonuçları ile kısmen farklılık göstermektedir. Brock Baskin vd. (2017) dışadönüklük boyutu ile zaman hırsızlığı alt boyutları arasında ilişkiye rastlamadıklarına ilişkin sonuçlar elde etmişlerdir.

Kişilik özelliklerinin bir diğer alt boyutu olan uyumluluk ile zaman hırsızlığı alt boyutlarından geleneksel ve teknolojik alt boyut arasında anlamlı bir ilişki tespit edilmemiştir. Ancak uyumluluk alt boyutu ile zaman hırsızlığının alt boyutu olan sosyal boyut arasında anlamlı bir ilişki saptanmıştır. Literatürde uyumlu olarak nitelendirilen, güvenilir, alçak gönüllü vb. kişilik özelliklerine sahip işgörenler sosyal anlamda zaman hırsızlığı davranışlarına eğilimli olabilmektedirler. Mesai saatleri içerisinde arkadaşlarıyla sohbet edip sorumluluklarını aksatabilen kişiler bu duruma örnek gösterilebilir. Uyumluluk alt boyutu ile ilgili elde edilen bu sonuçlar; Brock, M.E., Martin, L.E. ve Buckley, M.R. tarafından konu ile alakalı 2013 yılında yapılmış çalışmanın sonuçlarıyla karşılaştırılmış olup, birtakım paralellikler ve farklılıklar gözlemlenmiştir. Brock, M.E., Martin, L.E. ve Buckley, M.R. tarafından yapılan çalışma sonuçlarına göre uyumluluk alt boyutu zaman hırsızlığının geleneksel, teknolojik ve sosyal boyutu ile anlamlı bir ilişkiye sahiptir. Uyumluluk boyutunun zaman hırsızlığının sosyal alt boyut ile olan anlamlı ilişkinin tespit edilmesi bu iki çalışmanın paralel sonucu olurken geleneksel ve teknolojik alt boyutlar ile arasındaki ilişki açısından ise farklı sonuçlara ulaşılmıştır. Kişilik özelliklerinin alt boyutu olan sorumluluk boyutu ile zaman hırsızlığı ve alt boyutları arasında anlamlı bir ilişkiye rastlanmamıs olması da yine elde edilen sonuçlar arasındadır.

Kişilik özellikleri alt boyutu olan nevrotiklik ile zaman hırsızlığının tamamı, alt boyutlarından olan geleneksel ve sosyal boyut arasında anlamlı bir ilişki tespit edilmiş olup nevrotiklit ile teknolojik boyut arasında anlamlı bir ilişkiye rastlanmamıştır. işgörenlerin duygusal olarak değişiklik gösteren bir yapıya sahip olmaları, geleneksel ve sosyal anlamda zaman hırsızlı̆̆na yatkın oldukları anlamına gelirken bu durum teknolojik zaman hırsızlığı ile ilişkili değildir. Nevrotiklik alt boyutunun zaman hırsızlığının tamamı ile anlamlı bir ilişkide olduğuna dair elde edilen sonuç; Brock Baskin vd. (2017) tarafından yürütülen çalışmanın sonucu ile de paralellik taşımaktadır. Kişilik özelliklerinin alt boyutu olan açıklık boyutunun zaman hırsızlığı ve alt boyutları ile arasında anlamlı bir ilişkiye rastlanmamış olması elde edilen sonuçlar arasındadır. Elde edilen bu sonuç daha önce konu ile ilgili yapılmış olan "Time Banditry and Impression Management Behavior: Prediction and Profiling of Time Bandit Types" (Brock Baskin vd., 2017) adlı çalışmanın sonuçları ile paralellik göstermektedir. 
Çalışma kapsamında değişkenler arasındaki ilişki, korelasyon analizleri sonucunda tespit edilmesinin akabinde değişkenler arasındaki etkiyi ölçmek için de basit doğrusal regresyon ve çoklu regresyon analizleri uygulanmıştır. Regresyon analizleri sonucunda bağımsız değişken olan kişilik özelliklerinin, bağımlı değişken olan zaman hırsızlığı üzerinde pozitif yönde bir etkisi olduğu sonucuna ulaşılmıştır. Elde edilen bu sonuç işgörenlerin sahip oldukları kişilik özelliklerine göre zaman hırsızlığına ilişkin gösterdikleri davranışların değişkenlik gösterebildiği anlamına gelmektedir. Yani işgörenlerin karakteristik özellikleri zaman hırsızlığına yönelik davranış eğilimlerini etkilemektedir.

Analizler ve çalışmanın yürütülmesi aşamasında izlenen yollar çalışmanın ilgili bölümlerinde detaylı olarak verilmekte olup yine çalışma kapsamında oluşturulan hipotezlerin desteklenenleri ve desteklenmeyenleri de bulgular kısmında açılanmıştır. Çalışma belli bir süreç içerisinde tamamlanmış olup ve sosyal bir olgu olan insanların katılımı ile gerçekleştirilmiştir. Bu durum konu ile ilgili yapılacak farklı çalışmalarda farklı sonuçların elde edilebileceği anlamını da taşımaktadır. Zira sosyal araştırmalarda farklı süreçlerde farklı nedensellikler ve değişik psikolojik durumlar meydana gelebilmektedir.

\section{Kaynakça}

Akyüz, M., Yılmaz, F. T., ve Aldemir, K. (2020). Zaman Yönetim Becerilerinin Akademik Başarı ile İlişki. Elektronik Sosyal Bilimler Dergisi, 19(73), 414-424.

Aytürk, N. (2007). Yönetim sanatı: etkili yönetim ve yöneticilik becerileri. Ankara: Nobel Yayın Dağıtım.

Babadağ, M., ve Kerse, G. (2019). Zaman Hırsızlığı Ölçeğinin Türkçe Uyarlamasının Geçerliliğinin Yeniden Değerlendirilmesi ve Kişilik Özellikleri ile Zaman Hırsızlı̆̆ı Arasındaki İlişki. Bolu Abant İzzet Baysal Üniversitesi Sosyal Bilimler Enstitüsü Dergisi, 19(2), 419-438.

Brock Baskin, M.E., McKee, V. ve Buckley, M.R. (2017). Time Banditry and Impression Management Behavior: Prediction and Profiling of Time Bandit Types, Journal of Leadership \& Organizational Studies, 24(1), s.39-54.

Brock, M.E., Martin, L.E. ve Buckley, M.R. (2013). Time Theft in Organizations: The Development of the Time Banditry Questionnaire, International Journal of Selection and Assessment, 21(3), s.309-321.

Chen, Y. J., ve Tang, T. L. P. (2006). Attitude toward and propensity to engage in unethical behavior: Measurement invariance across major among university students. Journal of Business Ethics, 69(1), 7793.

Çetin, F., ve Varoğlu, A. K. (2009). Özellikler Bağlaminda Girişimcinin Beş Faktör Kişilik Örüntüsü. Savunma Bilimleri Dergisi, 8(2), 51-66.

Çoklar, I. (2014). Kişilik özellikleri ile bağışlama eğilimi arasındaki ilişkinin intikam güdüsü ve adalete duyarlılık temelinde incelenmesi (Doctoral dissertation, Ankara Üniversitesi Sosyal Bilimler Enstitüsü Psikoloji (Sosyal Psikoloji, Anabilim Dalı).

Ding, Z., Liu, W., Zhang, G., ve Wang, H. (2018). Supervisor narcissism and time theft: Investigating the mediating roles of emotional exhaustion and the moderating roles of attachment style. Frontiers in psychology, 9, 2215.

Erdem, R., Pirinçci, E. ve Dikmetaş, E., (2005), “Üniversite Öğrencilerinin Zaman Yönetimi Davranışları ve Bu Davranışların Akademik Başarı ile İlişkis"i, Manas Üniversitesi, Sosyal Bilimler Dergisi, (14), 67-177.

Ergün, Ö. (2017). Kişi kavramı ve çeşitleri. Dicle Üniversitesi Adalet Meslek Yüksekokulu Dicle Adalet Dergisi. (1)1,1-14.

Finley, M.;"Time Management for Leaders", SODC, University of Michigan, http://websrv.ewu.edu/groups/studentlife/Time_Management_for_Leader.pdf. /Erişim Tarihi: 12.05.2007

Gürbüz, M., ve Aydın, A. H. (2012). Zaman kavramı ve yönetimi. Kahramanmaraş Sütçü İmam Üniversitesi Sosyal Bilimler Dergisi, 9(2), 1-20. 
Hashim, N., Othman, A. K., \& Hamzah, M. I. (2013). The Influence of Personality Traits On The Relationship Between Work-Family Conflict and Job Satisfaction Among Married Women. The Influence of Personality Traits on the Relationship between Work-Family Conflict and Job Satisfaction among Married Women, 768-774.

Huczynski, A., ve Buchanan, D. A. (1997). Organizational Behaviour: Integrated Readings. Prentice Hall.

Liu, Y. ve Berry, CM (2013). Tecrübeli adaletsizlik ve zaman hırsızlı̆̆ı arasındaki ilişkiye kimlik, ahlaki ve eşitlik perspektifleri. İş etiği dergisi , 118 (1), 73-83.

McCrae, R. R., ve Costa Jr, P. T. (1995). Trait explanations in personality psychology. European Journal of Personality, 9(4), 231-252.

Özer, S. ve Güllüce, A. Ç. (2019). Örgütsel Sinizm ve İşe Yabancılaşma İlişkisi ve Etkisi: TRB1 Bölgesi Otel İşgörenleri Üzerinde Bir Araştırma. Anemon Muş Alparslan Üniversitesi Sosyal Bilimler Dergisi, 7, 3748.

Özyılmaz, Ö., ve Gülbetekin, G. (2018). İlkokul Öğretmenlerinin Kişilik Özellikleri ile Mesleki Yeterlilikleri Arasındaki İlişkinin İncelenmesi. (4)2, 231-246.

Passig, D. (2004), “Future-Time-Span As A Cognitive Skill In Future Studies”, Futures Research Quarterly, Vol $19(4), 27-42$.

Rodoplu, D. (2001). Stratejik yönetim düzeyinde zaman yönetimi ve yetki devri (Yüksek Lisans Tezi, Kocaeli Universitesi, Sosyal Bilimler Enstitusu).

Sekaran U. (2000). Research Methods for Business: A Skill Building Approach, Third Edition. USA: John Wiley \& Sons.

Sevi, E. S. (2009). Psikobiyolojik kişilik modeli ve beş faktör kişilik kuramı: Mizaç ve karekter envanteri (TCI) ile beş faktör kişilik envanterinin (5FKE) karşılaştırılması. Ege Üniversitesi Sosyal Bilimler Enstitüsü Klinik Psikoloji Anabilim Dalı Yüksek Lisans Tezi.

Smith, H. W. (1998). Hayatı ve Zamanı Yönetmenin 10 Doğal Yasası (Çev, Adalet Çelbiş). İstanbul, Sistem Yayıncilik.

Somer, O. (1998). Türkçe'de kişilik özelliği tanımlayan sıfatların yapısı ve beş faktör modeli. Türk Psikoloji Dergisi, 13(42), 17-32.

Soto, C. J., Kronauer, A., ve Liang, J. K. (2015). Five-Factor Model of Personality. The encyclopedia of adulthood and aging, 1-5.

Sucu, Y., (1996), Yönetsel Zamanın Etkin Kullanılması, El Kitabı, Bolu.

Trouba, E. J. (2009). A person-organization fit study of the big five personality model and attraction to organizations with varying compensation system characteristics. ProQuest Information \& Learning.

Turban, D. B., ve Lee, F. K. (2007). The role of personality in mentoring relationships. The handbook of mentoring at work: Theory, research, and practice, (9), 21-50.

Yazgan-İnanç, B. ve Yerlikaya, E .E. (2008). Kişilik Kuramları, Pegem Akademi, http://pegem.net/dosyalar/dokuman/27421Kisilik\%20Kuramlair\%206.\%20Baski.pdf: 1-358

Yazıcıŏlu, Y. ve Erdoğan, S. (2011). SPSS Uygulamalı Bilimsel Araştırma Yöntemleri. Ankara: Detay Yayincilik. 